\title{
The Construction of College Oral English Teaching Model Based on Multimodal Perspective
}

\author{
Yi Yang, Liyan Xiao \\ Baoding College, Baoding, China \\ Email: same512@163.com
}

How to cite this paper: Yang, Y., \& Xiao, L. Y. (2019). The Construction of College Oral English Teaching Model Based on Multimodal Perspective. Creative Education, 10, 423-428.

https://doi.org/10.4236/ce.2019.102030

Received: January 9, 2019

Accepted: February 18, 2019

Published: February 21, 2019

Copyright $\odot 2019$ by author(s) and Scientific Research Publishing Inc. This work is licensed under the Creative Commons Attribution International License (CC BY 4.0).

http://creativecommons.org/licenses/by/4.0/

\begin{abstract}
In the context of One Belt And One Road economic strategy, the increase of the international trade and Chinese and foreign cultural interaction mean that English practical abilities of contemporary college students should reach the higher standard. College oral English teaching model becomes the emphasis of college English teaching research.
\end{abstract}

\section{Keywords}

Multimodality, College English, Oral Language Class, Teaching Model

\section{The Main Problems in College Oral English Teaching Class}

In the current college oral English class, there are many problems. First, the teaching hours are limited and most of the time is occupied by the teacher's explanation. Second, students passively accept knowledge and lack of opportunities for oral expression. Third, the classroom atmosphere is dreary and many students are often absent because they reckon oral English class is optional. This paper analyzes the reasons for the poor teaching effect of college oral English teaching from three aspects: teacher, student and teaching environment.

1) Teacher's teaching mode cannot adapt to the needs of students

"Chinese students practice oral English mainly by classroom teaching. In the classroom, the language knowledge taught by the teacher is only declarative knowledge, which can be automatically translated into language skills by acquiring a kind of consciousness in specific and real communication activities. The pure knowledge explanation cannot play a key role basically for acquiring 
the practical language communication skills (Zhang \& Zhang, 2017)". However, teachers still dominate the oral teaching class at present and students' language inputs mainly rely on the single model of teachers' discourse. Too much time is occupied to implant knowledge into students' mind by teachers, which leaves too little time for students to practice, so it cannot meet the needs of students' large output. Although information technology has been applied in foreign language teaching, most teachers still follow the traditional teaching mode and method in oral English class. For example, most teachers tend to utilize multimedia courseware to assist teaching. But actually speaking, multimedia courseware can't play the role of fully mobilizing students' various senses, because the application of this mode is relatively single. The primary cause of problems is that teachers do not adopt renewed and more effective teaching method and mode in accordance with the feature of multimedia (Liang et al., 2017).

2) Students have a low sense of self-efficacy in oral English learning

"According to Bandura's theory of learning motivation, self-efficacy refers to an individual's subjective judgment of his ability to perform a certain behavior successfully which influences individuals' choice of behavior, effort and persistence" (Luo, 2017). At present, there is a general absence of confidence in oral expression by Chinese students who are ashamed of expressing voluntarily in the class and are unwilling to contact with the foreigners. Therefore a vicious circle is formed. Thus it can be seen that the low self-efficacy of students has a negative impact on oral English learning.

\section{The Construction of College Oral English Classroom Teaching Model from Multi-Modal Perspective}

1) Multi-modal teaching method to meet the needs of students

Compared with the traditional oral teaching mode, multi-modal teaching mode can meet the learning requirement of different students. The main method of oral English teaching is dialogue practice which follows the established dialogue script in English for oral practice. The merit of this method refers to learn a mass of oral communication contents by students and the defect of it refers to the monotony and the nonstandard of spoken English pronunciation. This teaching method has poor teaching effect for students with low self-discipline. From the perspective of students' actual English communication, the main problem lies in the inexperience in oral expression. Multimodal oral English teaching mode can improve the listening and pronunciation simultaneously to enhance student's speaking ability comprehensively.

The following points can be referred to in the implementation of multi-modal teaching mode. First, improve students' oral English ability through listening practice. In the process of listening practice, students need to listen to the dialogue material repeatedly so as to master the contents and pronunciation. In oral English learning, the best way is to be knowledgeable for the students and imitate in turn. At beginning, based on students' weak pronunciation and expres- 
sion, it is beneficial to apply listening practice to oral English teaching. Secondly, improve student's English pronunciation through following the audio. In the class, teachers organize students to read after them so as to find out the problems of pronunciation. By this, the quality of students' learning is gradually prompted. On the one hand, teachers can speed up to get students' attention; on the other hand, they can play at a slow speed to allow students to correct their pronunciation. By alternating the two speeds, students can feel the pleasure of English learning. In a word, teachers should make full use of audio to carry out oral teaching and give students enough chances to practice. Thirdly, learn native English through watching movies. Because of the authentic oral expression in movies, it is an effective way to improve students' oral English. Therefore, teachers need to collect and integrate these video materials related to oral teaching with appropriate editing. Through this method, it can enrich oral English teaching methods ( $\mathrm{Gu}, 2007)$. In oral practice, one point needs to be paid attention to, which is the ability of expressing their thoughts in English thinking.

2) Multi-modal discourse to stimulate students' subjective initiative

In traditional oral English teaching class, students follow the teachers to practice dialogue and listen to teachers' explanation of the skills in spoken English. Students accept oral teaching content passively and focus on memorize the content. This way of teaching is not conducive to the student-centered education because the main role of students has not been played. Multi-modal discourse can regulate the atmosphere of oral English class to let students indeed participate in classroom teaching activities ( $\mathrm{Li}, 2003)$. Thus, students can play the main role to improve oral English classroom teaching effect ultimately.

In the process of multi-modal discourse application, the following aspects should be taken into consideration. First, use body language to enhance understanding. British and American people express themselves with multiple body language and expressions. In oral English class, teachers should encourage students to use body language to express themselves. In the process of systematic English output, any language expression should be logical and complete. However, in the practical oral English expression, students like to use simple phrases or words for convenience and efficiency, because students who do not have a solid foundation in English prefer to use body language to help themselves to express, which can relieve students' embarrassment and can easily be understood. Secondly, make full use of image language to assist in understanding and memory. In "English in a minute", the emcee is required to introduce a usage of American slang within one minute with multiple body language and expressions to introduce the meaning and origin of slang. While he was addressing, the screen behind the emcee has a variety of pictures to accompany his explanation. The viewers memorize through seeing the picture and listening to the explanation with multiple senses simultaneously. In the end, students deepen the memory of oral expression and improve the learning effect by a large margin. So, in the oral English class, teachers should make full use of image language to moti- 
vate students' interest in learning. Thirdly, skillfully use music to improve students' learning interest and effect in oral English. In English teaching, teachers lead the students to sing what they have learned. This method utilizes music to make English learning more interesting, which can improve student's ardor in English learning. Moreover, Chinese pronunciation is different from English pronunciation, while the latter articulates it in the abdominal cavity and its mouth shape changes a lot. Like singing, it needs to pronounce with the public parts of the body and melodic fluctuations. So, in college oral English class, teachers should utilize music masterly which leads students to join in oral practice and make students revel in the wonderful music for strengthening oral pronunciation level. Fourthly, enrich teachers' own English expression corpus and use standard pronunciation. The emphasis of oral English teaching refers to make students pronounce exactly and speak idiomatic English. The teacher's accurate pronunciation helps the students imitate and rich conversational corpus can avoid students articulating rigidly (Pan, 2011). For instance, "how are you"? There are many answers. "I am fine, thank you. And you"? This is the most classic answer. "I am OK". This is the most common answer. Therefore, in English teaching, teachers should infiltrate the current British and American English expression habits to students as well as letting the students master the classical dialogues in the textbook. By means of this method, students can communicate in English flexibly and further be familiar with the current dialogue between native English speakers in case the foreigners' answers confuse the students. It should be noted that teachers should master the relation between students and multimodal discourse in the application of multimodal discourse in oral English class. Students' oral practice is the first priority with the supplement of multimodal expression. Hence, teachers should manage the class to arouse students' enthusiasm for learning with the multimodal discourse and earnestly implement the education view of students as the focus.

3) Multi-modal teaching scenarios to enhance the effect of situational teaching of oral English

Traditional oral English exercises make students remember the content of the oral expression through performing the established character dialogue and reflect the corresponding relations of utterances in the oral communication. But students are not familiar with the application scenarios of these spoken expressions which may cause students to use unidiomatic language in the actual oral expression or choose the improper sentences. Design of multi-modal teaching scene can let the students understand these spoken expressions in the simulated scene which can let students remember both the spoken language materials and the environment in which can make students' oral communication authentic and appropriate.

In the multi-modal teaching scene design, there are several points to emphasize. First, use drama or music to teach students. During the performance, students can deepen their understanding of the content in oral English materials 
and learn about the situations in which these spoken English should be used through using body language to match the script. Secondly, teach oral English by singing. Most English songs have their stories and each line expresses the mood and feelings of the protagonist. Therefore, students can get different English words and phrases in the pleasant process by learning some English songs. And students can correct their pronunciation in the process of imitating songs. This shows that it is helpful to enhance the students' understanding of the scene and optimize their pronunciation through imitating songs. Thirdly, see movies to make students experience the scene. There are so many life scenes in the movie. Students can better understand the oral English teaching content by watching the plot in movies, which help students to express their own thoughts more appropriate. Finally, teachers should integrate themselves into the situation to encourage students to feel and speak. Teachers have the flexibility to change the usage of the dialogue which can test the students' ability of adapting to the situation. Thus, college oral English teachers should try to design scenes as succinct as possible and transform complexity into simplicity creatively.

\section{Epilogue}

Multimodal oral English class in college can enrich the teaching mode to let all students enjoy the fun of oral English teaching. It is helpful for students-centered class to improve the teaching quality. The design of multi-modal teaching scenes in class can help students to express themselves in different situations appropriately. Therefore, college English teachers should master the effective methods in the established oral teaching class so as to improve the whole teaching effectiveness. Then they should carefully design the language situation to provide students with high-quality oral English teaching content.

\section{Funding}

The thesis is the research result of the teaching reform project of Baoding College-Study on the construction of multimodal interactive oral English teaching model (Project number: jg20170111).

\section{Conflicts of Interest}

The authors declare no conflicts of interest regarding the publication of this paper.

\section{References}

Gu, Y. G. (2007) Analysis of Multimedia and Multimodal Learning. Foreign Language Audio-Visual Teaching, 6, 4.

Li, Z. Z. (2003) The Analysis of Social Semiotics on Multimodal Discourse. Foreign Language Research, 4, 5.

Liang, P., He, Y. F., \& Guo, X. L. (2017) Multi-Modal Foreign Language Teaching and Its Preliminary Study on Effectiveness in the Network Multimedia Space. Journal of Inner Mongolia Normal University (Science of Education), 3, 7. 
Luo, X. L. (2017) Study on Audio-Visual and Oral Teaching of Undergraduate Business English from a Multi-Modal Perspective. Industry and Technology, 2, 12.

Pan, M. W. (2011) Communicative Competence from the Perspective of Multimodal: Reconstruction and Exploration. Shanghai: Shanghai Foreign Studies University.

Zhang, S. F., \& Zhang, L. D. (2017) Demand Analysis Based Multi-Modal Teaching Model in ESP Legal English Teaching English. Journal of Beijing University of Chemical Technology (Social Sciences), 3, 2. 